Bull. Chem. Soc. Ethiop. 2012, 26(2), 227-238.

Printed in Ethiopia

DOI: http://dx.doi.org/10.4314/bcse.v26i2.6

ISSN 1011-3924

(c) 2012 Chemical Society of Ethiopia

\title{
EFFECT OF DIELECTRIC CONSTANT OF MEDIUM ON CHEMICAL SPECIATION OF L-HISTIDINE COMPLEXES OF Co(II), Ni(II) AND Cu(II)
}

\author{
Raju Sala, Ananda Kumar Bokka, Bharath Kumar Naik Kethavath and Nageswara Rao \\ Gollapalli
}

Department of Inorganic and Analytical Chemistry, Andhra University, Visakhapatnam-530003, India

(Received December 21, 2010; revised January 19, 2012)

\begin{abstract}
Chemical speciation of binary complexes of $\mathrm{Co}(\mathrm{II}), \mathrm{Ni}$ (II) and $\mathrm{Cu}$ (II) ions with L-histidine have been studied $\mathrm{pH}$ metrically in the concentration range of $0-60 \% \mathrm{v} / \mathrm{v}$ DMSO-water mixtures maintaining an ionic strength of $0.16 \mathrm{M}$ at $303 \mathrm{~K}$. Alkalimetric titrations were carried out in different relative concentrations of metal and histidine. Stability constants of various models of binary complexes were refined with MINIQUAD75. The best-fit chemical models were selected based on statistical parameters and residual analysis. The species detected are $\mathrm{MLH}, \mathrm{ML}_{2}, \mathrm{ML}_{2} \mathrm{H}, \mathrm{ML}_{2} \mathrm{H}_{2}$ and $\mathrm{ML}_{2} \mathrm{H}_{4}$ for $\mathrm{Co}(\mathrm{II}) ; \mathrm{ML}_{2}, \mathrm{ML}_{2} \mathrm{H}, \mathrm{ML}_{2} \mathrm{H}_{2}$ and $\mathrm{ML}_{2} \mathrm{H}_{4}$ for $\mathrm{Ni}$ (II); and MLH, $\mathrm{ML}_{2}, \mathrm{ML}_{2} \mathrm{H}$ and $\mathrm{ML}_{2} \mathrm{H}_{2}$ for $\mathrm{Cu}(\mathrm{II})$. The chemical speciation, metal bioavailability and transportation are explained based on the distribution diagrams.
\end{abstract}

KEY WORDS: L-Histidine, Chemical speciation, Essential metals, Binary complexes, Bioavailability, DMSO

\section{INTRODUCTION}

Classical curve-fitting methods that use the least-squares methods $[1,2]$ are applied to estimate the number of species simultaneously present at equilibrium, their stoichiometries, and their stability constants. Bioavailability of a particular metal depends on its complex chemical reactions of dissolution, binding and complexation with the constituents of the environmental aquatic phase [3]. The metal complexes can be more active than the free ligands and some side effects may decrease upon complexation. In addition, the complexes can exhibit bioactivities which are not shown by the free ligand. The mechanism of action can involve binding to a metal ion in vivo or the metal complex may be a vehicle for activation of the ligand as the cytotoxic agent. Moreover, coordination may lead to significant reduction of drug-resistance $[4,5]$.

Speciation analysis is important in human biology, nutrition, toxicology and in clinical practice. The speciation study of essential metal ion complexes is useful to understand the role played by the active site cavities in biological molecules and the bonding behavior of protein residues with the metal ion. The species refined and their relative concentrations under the experimental conditions represent the possible forms of amino acids in bio-fluids.

L-Histidine (His) is an essential component of almost all the proteins. It provides metal binding sites in many enzymes. Due to the high reactivity of its imidazole group, histidine residue is often found at the active site of enzymes and involved directly in catalysis. It controls the transmission of metals in biological bases [6]. His containing antibacterial peptides have been reported in few peptides including histatin, clavanin and chrysophsin [7-12]. The formation and structure of histidine complexes with some transition metal ions have been studied in aqueous medium [13-19]. Speciation of the gold(III)-histidine complexes reveals important speciation information for both environmental and medical issues [20].

Cobalt is essential for the production of red blood cells. It acts as coenzyme in several biochemical processes. Cobalt is present in glutamate mutase, dialdehydase, methionine synthase, and arginase. It is present in non-corrin form in dipeptidase. The peptide-Ni

*Corresponding author. E-mail: gollapallinr@yahoo.com 
complexes have higher toxicity than the pure peptides. The glycine- and histidine-containing peptides may carry metal ions into the cells, where they can be released by the amino acid residues with high affinity for heavy metal ions. High flexibility of these peptides allows them free penetration through the membrane in the cytoplasm [21]. Active site of urease has two nickel atoms which are required for its activity. Nickel is also present [22] in carbon monoxide dehydrogenase, methyl-S-coenzyme-M-reductase and hydrogenase. Copper is one of the transition elements frequently found at the active site of proteins. In nature, a wide variety of copper proteins are essential constituents of aerobic organisms, including hemocyanins and enzymes.

The aim of the present study is to understand the role of metal ions at active site cavities in bioactive molecules like enzymes and proteins to know the effect of dielectric constant of the medium on the chemical speciation of the title systems. Histidine has been taken as a model compound for amino acid residues. Since the dielectric constant at the active site cavities is very small compared to that at bio-fluids, low dielectric constant is mimicked by using a water soluble organic solvent like dimethyl sulfoxide (DMSO). DMSO is a polar aprotic solvent. DMSO has a very strong affinity for water.

\section{EXPERIMENTAL}

\section{Chemicals}

DMSO (Merck, Mumbai) was used as received. Aqueous solutions of L-histidine and sodium chloride (E-Merck, Germany) were prepared in triple distilled water. Metal solutions of Co(II), $\mathrm{Ni}$ (II) and $\mathrm{Cu}$ (II) chlorides were prepared. To increase the solubility of His and to suppress the hydrolysis of metal salts, the mineral acid concentration in the above solutions was maintained at $0.05 \mathrm{M}$. To assess the errors that might have crept into the determination of the concentrations, the data were subjected to analysis of variance of one way classification (ANOVA). The strength (concentration) of alkali was determined using the Gran plot method $[23,24]$.

Apparatus

The titrimetric data were obtained with a calibrated ELICO (Model L1-120) pH-meter (readability 0.01) which can monitor the changes in $\mathrm{H}^{+}$concentration. The $\mathrm{pH}$ meter was calibrated with $0.05 \mathrm{M}$ potassium hydrogen phthalate in acidic region and $0.01 \mathrm{M}$ borax solution in alkaline region. The glass electrode was equilibrated in a well-stirred DMSO-water mixture containing inert electrolyte. All the titrations were carried out in the medium containing varying concentrations of DMSO $(0-60 \% \mathrm{v} / \mathrm{v})$ maintaining an ionic strength of $0.16 \mathrm{M}$ with sodium chloride at $303.0 \pm 0.1 \mathrm{~K}$. The effect of variations in asymmetry potential, liquid junction potential, activity coefficient, sodium ion error and dissolved carbon dioxide on the response of glass electrode were accounted for in the form of correction factor [25].

The emf of the cell may be expressed by the equation $\mathrm{E}=\mathrm{K}+(\mathrm{RT} / \mathrm{F}) \ln \mathrm{a}_{\mathrm{H}}+$ or $\mathrm{E}=\mathrm{K}+$ $0.0591 \mathrm{pH}$ at $25^{\circ} \mathrm{C}$, where $\mathrm{K}$ is a constant partly dependent upon the nature of the glass used for making the membrane. The value of $\mathrm{K}$ may vary slightly with time, and it is related to the existence of an asymmetry potential [26] in a glass electrode. Owing to the asymmetry potential, if a glass electrode is inserted into a test solution which is identical with the internal hydrochloric acid solution, the electrode shall have a small potential which is found to vary with time. Hence, glass electrode is standardized frequently using a buffer of known hydrogen activity. 
Procedure

For the determination of stability constants of metal-ligand binary species, initially titrations of strong acid with alkali were carried out at regular intervals to check whether complete equilibration was achieved. Then the calomel electrode was refilled with DMSO-water mixture of equivalent composition as that of titrand. In each of the titrations, the titrand consisted of approximately $1 \mathrm{mmol}$ mineral acid in a total volume of $50 \mathrm{~mL}$. Titrations with different ratios $(1: 2.5,1: 3.5,1: 5.0)$ of metal-to-ligand were carried out with $0.4 \mathrm{M}$ sodium hydroxide. Other experimental details are given elsewhere [27].

\section{Modeling strategy}

The computer program SCPHD [28] was used to calculate the correction factor. The binary stability constants were calculated with the computer program MINIQUAD75 [29] from the $\mathrm{pH}$ metric titration data. The correction factor and the protonation constants of histidine were fixed during the refinement of binary systems. During the modelling study, as the number of species increased, the models gave better statistics denoting the better fit. This indicates that the final models appropriately fit the experimental data. The variation of stability constants with the dielectric constant of the medium was analyzed on electrostatic grounds and on the basis of solute-solute and solute-solvent interactions.

\section{RESULTS AND DISCUSSION}

\section{Exhaustive modelling}

Existence of various species was determined by performing exhaustive modelling [30] and the results of a typical system are given in Table 1 . The models were evaluated assuming the simultaneous existence of different combinations of species. Models containing various numbers and combinations of species were generated using an expert system package CEES [31] and they were refined using MINIQUAD75. As the number of species increased, the models gave better statistics denoting the better fit. This indicates that the final model appropriately fits the experimental data. Such exhaustive modelling is performed on Co(II)histidine system in $10 \%$ DMSO. The table contains the stoichiometric coefficients and stability constants of the complex species, standard deviations in the stability constants and residual statistics of the models.

\section{Model validation}

\section{(a) Retrieval of protonation constants}

Protonation constants were retrieved from the metal-ligand titrations and compared with those obtained from proton-ligand titration data. The proximity of the two values confirms the existence of only reported metal-ligand species and accuracy of the titration data. Such comparisons for some typical systems are given in Table 2. Then simultaneous refinement of all the constants revealed that when the approximate constants are very close to the true values, either fixing some of the species or ingredient concentrations do not have any ill-effects on modelling studies. 
Table 1. Exhaustive modelling study performed on Co(II)-histidine system in $10 \%$ DMSO in $4.0-8.0 \mathrm{pH}$ range (number of experimental points, $\mathrm{NP}=45$ ).

\begin{tabular}{|c|c|c|c|c|c|c|c|c|c|c|}
\hline \multirow{2}{*}{$\begin{array}{c}\text { Model } \\
\text { no } \\
\end{array}$} & \multicolumn{5}{|c|}{$\log \beta \mathrm{mlh}(\mathrm{SD})$} & \multirow[t]{2}{*}{$\mathrm{U}_{\text {corr }}$} & \multirow[t]{2}{*}{$\chi^{2}$} & \multirow{2}{*}{$\begin{array}{l}\text { Skew } \\
\text {-ness }\end{array}$} & \multirow{2}{*}{$\begin{array}{c}\text { Kurto } \\
\text {-sis }\end{array}$} & \multirow[t]{2}{*}{$\mathrm{R}$-factor } \\
\hline & 111 & 120 & 121 & 122 & 124 & & & & & \\
\hline 1 & $14.19(15)$ & $\begin{array}{ll}--- \\
\end{array}$ & $\begin{array}{ll}--- \\
\end{array}$ & $\begin{array}{ll}--- \\
\end{array}$ & $\begin{array}{ll}--- \\
-1\end{array}$ & 179.77 & 46.63 & -0.46 & 3.38 & 0.1038 \\
\hline 2 & ---- & $13.35(10)$ & ---- & ---- & ---- & 13.36 & 20.91 & -1.08 & 2.71 & 0.0283 \\
\hline 3 & $\begin{array}{ll}--- \\
\end{array}$ & ---- & $19.54(13)$ & ---- & ---- & 17.14 & 27.43 & 0.86 & 5.65 & 0.0320 \\
\hline 4 & ---- & $-\cdots-$ & ---- & $26.02(65)$ & ---- & 126.14 & 35.37 & -0.27 & 4.40 & 0.0869 \\
\hline 5 & ---- & ---- & ---- & ---- & Rejected & ---- & ---- & $\begin{array}{l}--- \\
\end{array}$ & ---- & ---- \\
\hline 6 & $13.25(16)$ & $13.73(15)$ & ---- & ---- & --- & 3.63 & 14.63 & -0.73 & 2.45 & 0.0146 \\
\hline 7 & $12.45(51)$ & --- & $19.68(19)$ & ---- & ---- & 16.93 & 59.90 & 0.96 & 6.22 & 0.0315 \\
\hline 8 & Rejected & ---- & ---- & $26.02(65)$ & ---- & 129.07 & 35.37 & -0.27 & 4.40 & 0.0869 \\
\hline 9 & Rejected & ---- & ---- & --- & Rejected & ---- & ---- & ---- & ---- & ---- \\
\hline 10 & ---- & 12.77(10) & $19.34(7)$ & ---- & ---- & 2.84 & 2.30 & -0.75 & 3.25 & 0.0129 \\
\hline 11 & ---- & $13.26(5)$ & ---- & $25.33(5)$ & ---- & 1.11 & 11.07 & -0.53 & 3.65 & 0.0081 \\
\hline 12 & ---- & $13.35(10)$ & ---- & ---- & Rejected & 13.67 & 20.91 & -1.08 & 2.71 & 0.0283 \\
\hline 13 & ---- & ---- & $19.55(11)$ & $24.07(15)$ & ---- & 17.49 & 25.65 & 0.88 & 5.73 & 0.0320 \\
\hline 14 & ---- & ---- & $19.55(17)$ & ---- & $33.99(410)$ & 17.53 & 24.59 & 0.85 & 5.63 & 0.0320 \\
\hline 15 & ---- & ---- & ---- & Rejected & Rejected & ---- & ---- & ---- & ---- & ---- \\
\hline 16 & $12.88(5)$ & $13.19(5)$ & $19.53(4)$ & ---- & ---- & 0.37 & 2.07 & 0.62 & 3.88 & 0.0046 \\
\hline 17 & Rejected & $13.26(5)$ & ---- & $25.33(5)$ & ---- & 1.14 & 11.07 & -0.53 & 3.65 & 0.0081 \\
\hline 18 & $13.39(27)$ & $13.86(25)$ & ---- & ---- & $35.08(100)$ & 3.71 & 12.26 & -0.74 & 2.50 & 0.0146 \\
\hline 19 & $12.45(51)$ & --- & $19.68(19)$ & Rejected & ---- & 16.93 & 59.90 & 0.96 & 6.22 & 0.0315 \\
\hline 20 & $13.50(16)$ & ---- & $20.62(15)$ & ---- & $36.56(18)$ & 16.79 & 39.99 & 0.96 & 6.21 & 0.0310 \\
\hline 21 & Rejected & ---- & ---- & Rejected & Rejected & ---- & ---- & ---- & ---- & ---- \\
\hline 22 & ---- & $13.04(4)$ & $19.12(60)$ & $25.12(5)$ & ---- & 0.54 & 33.83 & -0.33 & 4.05 & 0.0055 \\
\hline 23 & ---- & $12.77(10)$ & $19.34(7)$ & ---- & Rejected & 2.84 & 2.30 & -0.75 & 3.25 & 0.0129 \\
\hline 24 & ---- & $13.60(11)$ & ---- & $25.77(13)$ & $35.81(22)$ & 0.77 & 5.98 & -1.02 & 4.55 & 0.0066 \\
\hline 25 & ---- & ---- & $19.75(32)$ & $24.68(100)$ & $35.36(93)$ & 17.83 & 26.96 & 0.86 & 5.62 & 0.0319 \\
\hline 26 & $12.67(10)$ & $13.16(4)$ & $19.40(6)$ & $24.82(13)$ & ---- & 0.30 & 24.59 & 0.54 & 4.43 & 0.0041 \\
\hline 27 & $13.06(11)$ & $13.34(10)$ & $19.69(9)$ & --- & $35.16(31)$ & 91.22 & 2.54 & 0.78 & 4.34 & 0.0043 \\
\hline 28 & $13.50(16)$ & ---- & $20.62(150)$ & Rejected & $36.56(18)$ & 16.79 & 39.99 & 0.96 & 6.21 & 0.0310 \\
\hline 29 & ---- & $13.26(8)$ & $19.24(8)$ & $25.42(10)$ & $35.36(21)$ & 0.44 & 7.28 & -0.86 & 4.80 & 0.0050 \\
\hline 30 & $12.15(71)$ & $13.65(15)$ & ---- & $25.80(15)$ & $35.87(25)$ & 0.78 & 8.11 & -1.02 & 4.60 & 0.0066 \\
\hline 31 & $12.89(11)$ & $13.41(8)$ & $19.59(8)$ & $25.25(11)$ & $35.50(17)$ & 0.20 & 32.53 & 0.33 & 7.74 & 0.0033 \\
\hline
\end{tabular}

Table 2. Retrieval of protonation constants from metal-ligand titration data.

\begin{tabular}{|c|c|c|c|c|c|c|}
\hline \multirow{2}{*}{$\begin{array}{c}\text { DMSO } \\
\% \mathrm{v} / \mathrm{v}\end{array}$} & \multicolumn{3}{|c|}{$\begin{array}{c}\text { From proton-ligand } \\
\text { titration data }\end{array}$} & \multicolumn{3}{c|}{$\begin{array}{c}\text { From Co(II)-His } \\
\text { titration data }\end{array}$} \\
\cline { 2 - 8 } & $\log \beta_{1}$ & $\log \beta_{2}$ & $\log \beta_{3}$ & $\log \beta_{1}$ & $\log \beta_{2}$ & $\log \beta_{3}$ \\
\hline 00 & 9.26 & 15.40 & 17.14 & 9.26 & 15.39 & 17.09 \\
\hline 10 & 9.42 & 15.57 & 17.43 & 9.37 & 15.53 & 17.43 \\
\hline 20 & 9.58 & 15.70 & 17.69 & 9.51 & 15.48 & 17.73 \\
\hline 30 & 9.66 & 15.76 & 17.82 & 9.72 & 15.79 & 18.16 \\
\hline 40 & 9.63 & 15.60 & 17.91 & 9.49 & 15.45 & 18.27 \\
\hline 50 & 9.63 & 15.45 & 17.94 & 9.71 & 15.45 & 18.60 \\
\hline 60 & 9.70 & 15.33 & 18.08 & 9.81 & 15.37 & 18.50 \\
\hline
\end{tabular}




\section{(b) Introduction of pessimistic errors}

In order to rely upon the best chemical model for critical evaluation and application under varied experimental conditions with different accuracies of data acquisition, an investigation was made by introducing pessimistic errors in the influential parameters [32] like concentrations of alkali, mineral acid, ligand and metal (Table 3). The order of the ingredients that influence the magnitudes of stability constants due to incorporation of errors is alkali $>$ acid $>$ ligand $>$ metal. Some species are even rejected when errors are introduced in the concentrations. This study confirms the appropriateness of the chosen best-fit models. This study also indicates the relative sensitivities of model parameters.

Table 3. Effect of errors in influential parameters on cobalt-histidine stability constants in $20 \% \mathrm{v} / \mathrm{v}$ DMSOwater mixture.

\begin{tabular}{|c|c|c|c|c|c|c|}
\hline \multirow[t]{2}{*}{ Ingredient } & \multirow[t]{2}{*}{$\%$ Error } & \multicolumn{5}{|c|}{$\log \beta_{\mathrm{mlh}}(\mathrm{SD})$} \\
\hline & & MLH & $\mathrm{ML}_{2}$ & $\mathrm{ML}_{2} \mathrm{H}$ & $\mathrm{ML}_{2} \mathrm{H}_{2}$ & $\mathrm{ML}_{2} \mathrm{H}_{4}$ \\
\hline & 0 & $13.19(13)$ & $14.13(9)$ & $20.26(9)$ & $26.03(11)$ & $36.11(15)$ \\
\hline \multirow{4}{*}{ Alkali } & -5 & Rejected & $11.56(16)$ & $19.32(12)$ & $25.48(16)$ & $36.24(21)$ \\
\hline & -2 & $12.81(12)$ & $13.25(7)$ & 19.93(6) & $25.69(8)$ & $36.09(11)$ \\
\hline & +2 & $13.89(44)$ & $14.95(42)$ & $20.89(4)$ & Rejected & $35.85(84)$ \\
\hline & +5 & $18.25(310)$ & $19.90(310)$ & $25.22(311)$ & Rejected & Rejected \\
\hline \multirow{4}{*}{ Acid } & -5 & $18.76(284)$ & $20.52(284)$ & $25.97(285)$ & Rejected & Rejected \\
\hline & -2 & $13.72(18$ & $14.80(17)$ & $20.76(15)$ & Rejected & Rejected \\
\hline & +2 & $12.72(15)$ & $13.34(7)$ & $19.94(7)$ & $25.82(8)$ & $36.31(11)$ \\
\hline & +5 & Rejected & $12.10(28)$ & $19.59(24)$ & $25.78(29)$ & $36.79(33)$ \\
\hline \multirow{4}{*}{ Ligand } & -5 & $13.17(16)$ & $14.24(11)$ & $20.34(11)$ & $26.39(11)$ & $36.78(13)$ \\
\hline & -2 & $13.18(14)$ & $14.16(9)$ & $20.28(10)$ & $26.16(11)$ & $36.38(14)$ \\
\hline & +2 & $13.46(15)$ & $14.11(13)$ & $20.43(13)$ & Rejected & $35.50(38)$ \\
\hline & +5 & $13.42(7)$ & $14.15(7)$ & $20.45(5)$ & Rejected & Rejected \\
\hline \multirow{4}{*}{ Metal } & -5 & $13.48(20)$ & $14.23(18)$ & $20.45(18)$ & Rejected & $35.73(41)$ \\
\hline & -2 & $13.48(17)$ & $14.13(16)$ & $20.44(16)$ & Rejected & $35.78(34)$ \\
\hline & +2 & 13.21(11) & $14.07(8)$ & $20.28(8)$ & $26.02(9)$ & $36.14(13)$ \\
\hline & +5 & $13.24(9)$ & $13.99(7)$ & $20.29(7)$ & $26.01(8)$ & $36.18(11)$ \\
\hline \multirow{4}{*}{$\log F$} & -5 & $13.18(13)$ & $14.10(9)$ & $20.25(9)$ & $26.03(10)$ & $36.14(15)$ \\
\hline & -2 & $13.18(13)$ & 14.12(9) & $20.26(9)$ & $26.03(11)$ & $36.12(15)$ \\
\hline & +2 & $13.19(13)$ & $14.14(9)$ & $20.27(9)$ & $26.03(11)$ & $36.10(15)$ \\
\hline & +5 & $13.19(13)$ & $14.16(9)$ & $20.28(10)$ & $26.03(11)$ & $36.08(15)$ \\
\hline \multirow{4}{*}{ Volume } & -5 & $13.16(13)$ & $14.09(9)$ & $20.22(9)$ & $25.99(11)$ & $36.07(15)$ \\
\hline & -2 & $13.18(13)$ & 14.11(9) & $20.25(9$ & $26.02(11$ & $36.10(15)$ \\
\hline & +2 & $13.19(13)$ & $14.15(9)$ & $20.28(9)$ & $26.05(11)$ & $36.13(15)$ \\
\hline & +5 & $13.21(13)$ & $14.17(9)$ & $20.31(9)$ & $26.07(11)$ & $36.15(15)$ \\
\hline
\end{tabular}

\section{Best fit models}

The results of the best-fit models that contain the type of species and overall formation constants along with some of the important statistical parameters are given in Table 4. A very low standard deviation in $\log \beta$ values indicates the precision of these parameters. Small values of Ucorr (sum of squares of deviations in concentrations of ingredients at all experimental points corrected for degrees of freedom) indicate that the experimental data can be represented by the models. Small values of mean, standard deviation and mean deviation for the systems corroborate that the residuals are around a zero mean with little dispersion. For an ideal normal 
distribution, the values of kurtosis and skewness should be three and zero, respectively. Kurtosis is a measure of the peakedness of the error distribution near a modal value. For an ideal normal distribution kurtosis value should be three (mesokurtic). If the kurtosis is less than three, the peak of the error distribution curve is flat (platykurtic) and if the kurtosis is greater than three, the distribution shall have sharp peak (leptokurtic). The kurtosis values in the present study indicate that the residuals form leptokurtic as well as platykurtic patterns and very few are nearer to mesokurtic patterns. The values of skewness recorded in Table 4 are between -0.67 and 1.34. These data evince that the residuals form part of a normal distribution. Hence, the least-squares method can be applied to the present data. The sufficiency of the model is further evident from the low crystallographic R-value recorded. These statistical parameters thus show that the best-fit models portray the metal-ligand species in DMSO-water mixtures.

Table 4. Best-fit chemical models of histidine complexes of $\mathrm{Co}(\mathrm{II}), \mathrm{Ni}$ (II) and $\mathrm{Cu}$ (II) in $\mathrm{DMSO}$-water mixtures (temperature $=303 \mathrm{~K}$, ionic strength $=0.16 \mathrm{M}$ ).

\begin{tabular}{|c|c|c|c|c|c|c|c|c|c|c|c|c|}
\hline \multirow{2}{*}{$\begin{array}{c}\text { DMSO } \\
\% \mathrm{v} / \mathrm{v}\end{array}$} & \multicolumn{5}{|c|}{$\log \beta(\mathrm{SD})$} & \multirow{2}{*}{$\begin{array}{l}\mathrm{pH}- \\
\text { range }\end{array}$} & \multirow[t]{2}{*}{ NP } & \multirow[t]{2}{*}{$\mathrm{U}_{\text {corr }}$} & \multirow{2}{*}{$\begin{array}{c}\text { Skew- } \\
\text { ness }\end{array}$} & \multirow{2}{*}{$\begin{array}{l}\text { Kurt- } \\
\text { osis }\end{array}$} & \multirow[t]{2}{*}{$\chi^{2}$} & \multirow[t]{2}{*}{ R-factor } \\
\hline & MLH & $\mathrm{ML}_{2}$ & $\mathrm{ML}_{2} \mathrm{H}$ & $\mathrm{ML}_{2} \mathrm{H}_{2}$ & $\mathrm{ML}_{2} \mathrm{H}_{4}$ & & & & & & & \\
\hline \multicolumn{13}{|c|}{$\mathrm{Co}(\mathrm{II})$} \\
\hline 00.0 & $12.68(20)$ & $12.83(14)$ & $19.09(14)$ & 24.91(19) & $35.35(26)$ & $4.0-8.0$ & 45 & 0.60 & 0.47 & 3.86 & 7.28 & 0.0058 \\
\hline 10.0 & $12.89(11)$ & $13.41(8)$ & $19.59(8)$ & $25.25(11)$ & $35.50(17)$ & $4.0-8.0$ & 45 & 0.20 & 0.33 & 7.74 & 32.53 & 0.0033 \\
\hline 20.0 & $13.19(13)$ & $14.13(9)$ & $20.26(9)$ & $26.03(11)$ & $36.11(15)$ & $4.0-8.0$ & 44 & 0.20 & 1.20 & 7.60 & 26.06 & 0.0034 \\
\hline 30.0 & $12.82(26)$ & 14.01(12) & $20.41(11)$ & $26.00(15)$ & $35.79(27)$ & $4.0-8.0$ & 43 & 0.61 & 0.22 & 2.64 & 2.53 & 0.0057 \\
\hline 40.0 & $12.56(54)$ & 14.61(15) & $20.34(18)$ & $26.08(18)$ & $35.43(37)$ & $4.0-7.0$ & 46 & 1.17 & 0.34 & 4.51 & 21.36 & 0.0078 \\
\hline 50.0 & $13.02(23)$ & $14.72(12)$ & $21.02(12)$ & $26.37(14)$ & $35.83(18)$ & $4.2-8.0$ & 45 & 0.37 & -0.49 & 3.99 & 14.16 & 0.0045 \\
\hline 60.0 & $13.66(54)$ & $15.69(46)$ & $21.92(44)$ & $26.58(62)$ & $35.75(62)$ & $4.0-8.0$ & 43 & 3.58 & -0.14 & 3.27 & 9.60 & 0.0138 \\
\hline \multicolumn{13}{|c|}{$\mathrm{Ni}(\mathrm{II})$} \\
\hline 00.0 & ---- & $16.13(7)$ & $21.38(12)$ & $26.99(6)$ & $35.39(8)$ & $2.0-7.0$ & 93 & 0.80 & -0.28 & 4.78 & 26.75 & 0.0047 \\
\hline 10.0 & ---- & $16.65(6)$ & 21.73(12) & $27.29(5)$ & $35.25(8)$ & $2.0-7.0$ & 95 & 0.65 & -.0 .25 & 4.42 & 33.79 & 0.0041 \\
\hline 20.0 & ---- & $16.94(12)$ & $22.32(11)$ & $27.62(12)$ & $35.59(29)$ & $2.7-7.0$ & 58 & 1.15 & 1.34 & 8.43 & 44.11 & 0.0071 \\
\hline 30.0 & ---- & $17.87(24)$ & $23.04(23)$ & $28.44(24)$ & $36.66(32)$ & $3.2-7.0$ & 46 & 1.27 & 0.53 & 3.64 & 1.83 & 0.0079 \\
\hline 40.0 & --- & $18.75(8)$ & $22.98(14)$ & $28.08(5)$ & $35.05(15)$ & $2.2-7.0$ & 85 & 1.18 & -0.67 & 5.54 & 17.09 & 0.0059 \\
\hline 50.0 & \begin{tabular}{|l|}
---- \\
\end{tabular} & $18.98(11)$ & 23.61(13) & $28.41(10)$ & $35.40(21)$ & $3.0-6.0$ & 49 & 0.84 & 0.22 & 3.90 & 8.48 & 0.0060 \\
\hline 60.0 & \begin{tabular}{l|l|}
--- \\
\end{tabular} & $19.64(9)$ & $24.04(12)$ & $28.68(8)$ & $35.34(18)$ & $3.1-7.0$ & 53 & 0.60 & 0.05 & 3.48 & 5.68 & 0.0053 \\
\hline \multicolumn{13}{|c|}{$\mathrm{Cu}(\mathrm{II})$} \\
\hline 00.0 & $14.23(7)$ & $17.97(6)$ & $24.03(4)$ & $28.21(5)$ & ----- & $2.8-7.5$ & 52 & 0.35 & -0.09 & 3.75 & 10.77 & 0.0042 \\
\hline 10.0 & $14.57(4)$ & $18.44(4)$ & $24.58(3)$ & $28.53(4)$ & ----- & $2.8-7.5$ & 51 & 0.17 & -0.29 & 3.80 & 3.39 & 0.0029 \\
\hline 20.0 & $14.91(4)$ & $19.29(5)$ & $25.27(3)$ & $29.05(5)$ & ----- & $2.8-7.5$ & 52 & 0.21 & -0.33 & 3.89 & 6.56 & 0.0032 \\
\hline 30.0 & $14.56(6)$ & $18.41(5)$ & $24.87(4)$ & $29.14(3)$ & ----- & $2.8-7.5$ & 49 & 0.26 & -0.34 & 4.01 & 11.42 & 0.0035 \\
\hline 40.0 & $14.70(6)$ & $18.58(7)$ & $24.97(5)$ & $29.02(5)$ & ----- & $2.8-7.5$ & 57 & 0.49 & 0.50 & 4.44 & 9.91 & 0.0047 \\
\hline 50.0 & 15.11(6) & $19.50(7)$ & $25.48(6)$ & $29.41(4)$ & ----- & $2.8-7.5$ & 55 & 0.39 & -0.45 & 4.05 & 3.87 & 0.0043 \\
\hline 60.0 & $15.63(5)$ & $20.41(5)$ & $26.18(5)$ & $30.15(3)$ & ----- & $2.8-7.5$ & 54 & 0.11 & -0.58 & 7.80 & 33.36 & 0.0022 \\
\hline
\end{tabular}

Ucorr $=\mathrm{U} /(\mathrm{NP}-\mathrm{m}) \times 10^{8}$, where, $\mathrm{m}=$ number of species; $\mathrm{NP}=$ number of experimental points; $\mathrm{SD}=$ standard deviation.

\section{Influence of dielectric constant}

The water-DMSO mixture influences microscopic dynamics of solvated ions $[33,34]$ and dye molecules $[35,36]$ so that these solutes exhibit a qualitatively different behavior compared to the behavior in other solvents. The variation of overall stability constant values or change in free energy with co-solvent content depends upon two factors, viz., electrostatic and nonelectrostatic. Born's [37] classical treatment holds good in accounting for the electrostatic contribution to the free energy change. According to this treatment, the energy of electrostatic interaction is related to dielectric constant. Hence, the $\log \beta$ values should vary linearly as a 
function of the reciprocal of the dielectric constant (1/D) of the medium, which is observed in the present study (Figure 1). The linear variation indicates that electrostatic forces dominate the equilibrium process under the present experimental conditions. It also indicates that the dielectric constant or long range interactions are responsible for the stability trend.
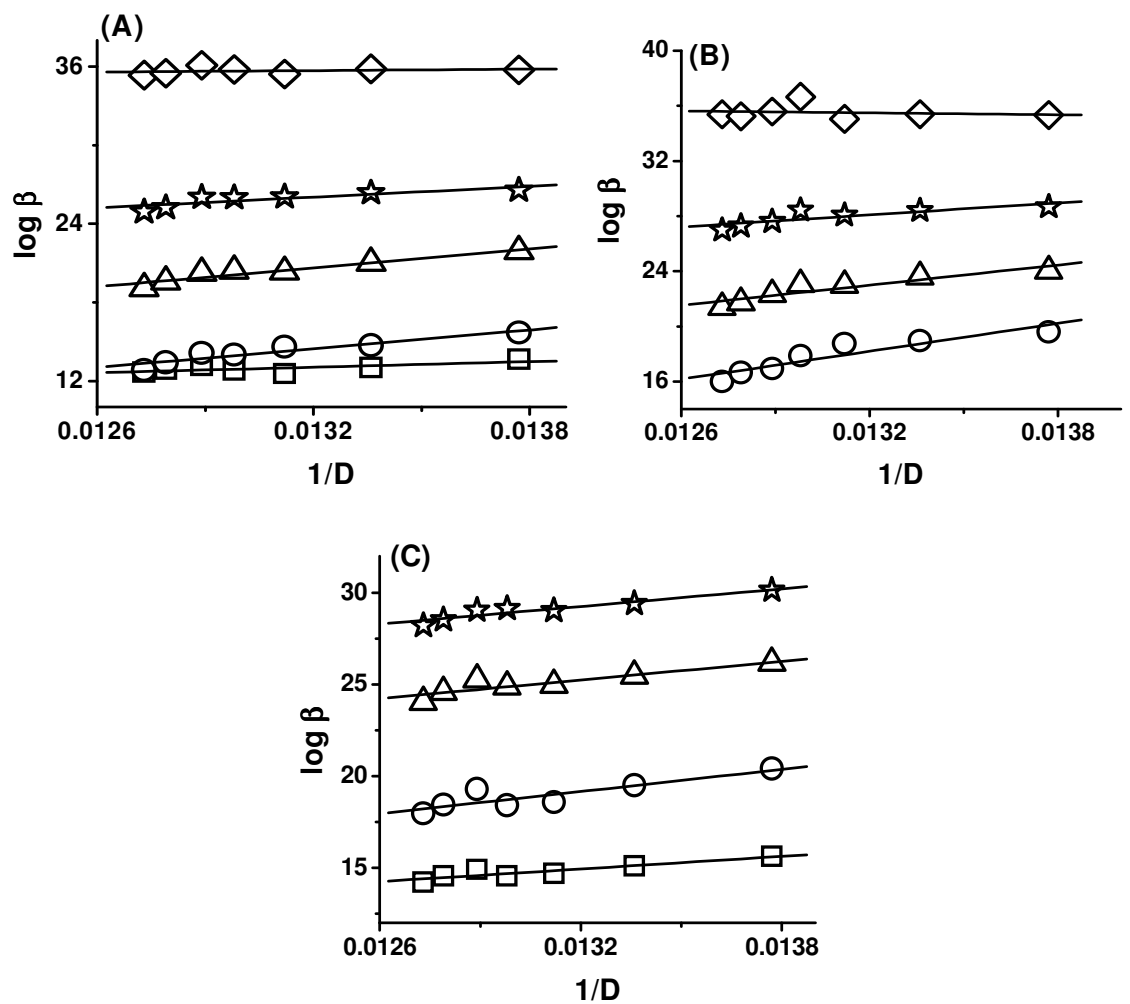

Figure 1. Variation of stability constant values of metal-histidine complexes with reciprocal of dielectric constant in DMSO-water mixtures at temperature $=303 \mathrm{~K}$, ionic strength $=$ 0.16 M. (A) $\mathrm{Co}(\mathrm{II})$, (B) $\mathrm{Ni}(\mathrm{II})$ and (C) $\mathrm{Cu}$ (II) ; ( $\square$ ) $\log \beta_{111}$, (o) $\log \beta_{120}$ ( $\Delta$ ) $\log \beta_{121}$, (敢) $\log \beta_{122}(\diamond) \log \beta_{124}$.

\section{Distribution diagrams}

His has one dissociable carboxyl proton and its amino and imidazole groups can associate with one proton each. The different forms of His are $\mathrm{LH}_{3}{ }^{+2}, \mathrm{LH}_{2}{ }^{+}$and $\mathrm{LH}$ in the $\mathrm{pH}$ regions 1.5-3.0, 2.0-7.0 and 5.0-9.0, respectively. Hence, the plausible species in different systems can be predicted from these data. The species refined and determined are $M L H, M_{2}, M_{2} H, M_{2} \mathrm{H}_{2}$ and $\mathrm{ML}_{2} \mathrm{H}_{4}$ for $\mathrm{Co}(\mathrm{II}) ; \mathrm{ML}_{2}, \mathrm{ML}_{2} \mathrm{H}, \mathrm{ML}_{2} \mathrm{H}_{2}$ and $\mathrm{ML}_{2} \mathrm{H}_{4}$ for $\mathrm{Ni}(\mathrm{II})$; $\mathrm{MLH}, \mathrm{ML}_{2}, \mathrm{ML}_{2} \mathrm{H}$ and $\mathrm{ML}_{2} \mathrm{H}_{2}$ for $\mathrm{Cu}$ (II) in the $\mathrm{pH}$ ranges 3.0-8.0, 2.0-7.0 and 3.0-8.0, respectively. The formation of various binary complex species is shown in the following equilibria. The charges of species are omitted for simplicity. 


$\begin{array}{lll}\mathrm{M}(\mathrm{II})+2 \mathrm{LH}_{3} & \rightleftharpoons & \mathrm{ML}_{2} \mathrm{H}_{4}+2 \mathrm{H}^{+} \\ \mathrm{ML}_{2} \mathrm{H}_{4} & \rightleftharpoons & \mathrm{ML}_{2} \mathrm{H}_{3}+\mathrm{H}^{+} \\ \mathrm{ML}_{2} \mathrm{H}_{3} & \rightleftharpoons & \mathrm{ML}_{2} \mathrm{H}_{2}+\mathrm{H}^{+} \\ \mathrm{M}(\mathrm{II})+2 \mathrm{LH}_{3} & \rightleftharpoons & \mathrm{ML}_{2} \mathrm{H}_{2}+4 \mathrm{H}^{+} \\ \mathrm{MLH}+\mathrm{LH}_{2} & \rightleftharpoons & \mathrm{ML}_{2} \mathrm{H}_{2}+\mathrm{H}^{+} \\ \mathrm{ML} \mathrm{H}_{2} & \rightleftharpoons & \mathrm{ML}_{2} \mathrm{H}+\mathrm{H}^{+} \\ \mathrm{M}(\mathrm{II})+\mathrm{LH}_{3} & \rightleftharpoons & \mathrm{MLH}^{2}+2 \mathrm{H}^{+} \\ \mathrm{M}(\mathrm{II})+\mathrm{LH}_{2} & \rightleftharpoons & \mathrm{MLH}^{2} \mathrm{H}^{+} \\ \mathrm{M}(\mathrm{II})+2 \mathrm{LH}_{2} & \rightleftharpoons & \mathrm{ML}_{2} \mathrm{H}_{2}+2 \mathrm{H}^{+} \\ \mathrm{M}(\mathrm{II})+2 \mathrm{LH}_{2} & \rightleftharpoons & \mathrm{ML}_{2} \mathrm{H}+3 \mathrm{H}^{+} \\ \mathrm{M}(\mathrm{II})+2 \mathrm{LH}_{2} & \rightleftharpoons & \mathrm{ML}_{2}+4 \mathrm{H}^{+} \\ \mathrm{M}(\mathrm{II})+2 \mathrm{LH} & \rightleftharpoons & \mathrm{ML}_{2}+2 \mathrm{H}^{+} \\ \mathrm{ML} \mathrm{HL}_{2} \mathrm{H} & & \mathrm{ML}_{2}+\mathrm{H}^{+}\end{array}$

Some typical distribution diagrams in DMSO-water mixtures are shown in Figure 2 which indicate the formation of binary complexes of $\mathrm{Co}$ (II), $\mathrm{Ni}$ (II) and $\mathrm{Cu}$ (II). At a pH below 3.0 $\mathrm{ML}_{2} \mathrm{H}_{4}$ species is formed for $\mathrm{Co}$ (II) and $\mathrm{Ni}$ (II) [Equilibrium 1]. This might have been deprotonated to $\mathrm{ML}_{2} \mathrm{H}_{3}$ which might have been quickly deprotonated to $\mathrm{ML}_{2} \mathrm{H}_{2}$ above a $\mathrm{pH}$ of 3.0 [Equilibria 2 and 3]. $\mathrm{ML}_{2} \mathrm{H}_{3}$ could not be detected probably due its instability or it may be a transient species. Simultaneous increase in the concentrations of $\mathrm{ML}_{2} \mathrm{H}_{2}$ and $\mathrm{MLH}$ supports Equilibria 3, 5 and 8. Simultaneous formation of $\mathrm{ML}_{2} \mathrm{H}_{2}$ and $\mathrm{ML}_{2} \mathrm{H}$ supports Equilibria 9 and 10. $\mathrm{ML}_{2} \mathrm{H}_{2}$ deprotonates to $\mathrm{ML}_{2} \mathrm{H}$ with increasing $\mathrm{pH}$ [Equilibrium 6]. $\mathrm{ML}_{2}$ is formed in the order of Equilibria 11-13 with increasing $\mathrm{pH}$. In the case of $\mathrm{Cu}$-His complexes (Figure 2C) concentrations of $\mathrm{LH}_{3}$ and free metal ion decrease with increasing concentration of MLH species [Equilibrium 7]. Formation of $\mathrm{ML}_{2} \mathrm{H}_{2}$ can be explained from Equilibria 4, 5 and 9. Successive deprotonation of $\mathrm{ML}_{2} \mathrm{H}_{2}$ beyond a $\mathrm{pH}$ of 4.0 forms $\mathrm{ML}_{2} \mathrm{H}$ and $\mathrm{ML}_{2}$ [Equilibria 6 and 13]. 

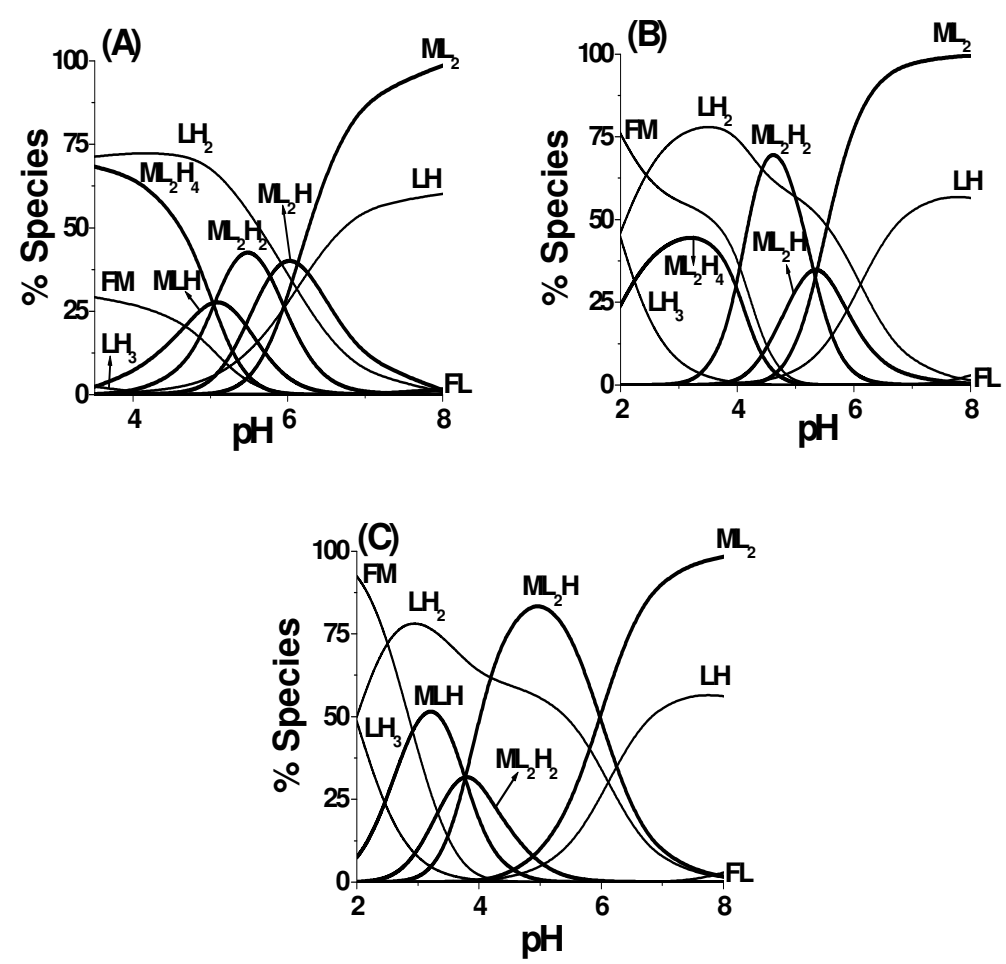

Figure 2. Distribution diagrams of histidine complexes in 20\% v/v DMSO-water mixture at 303 $\mathrm{K}$ and $0.16 \mathrm{M}$ ionic strength. FM and FL are the free metal and the most deprotonated form of the ligand, respectively. (A) $\mathrm{Co}$ (II) $=0.0935 \mathrm{mmol}$, (B) $\mathrm{Ni}$ (II) $=0.0978 \mathrm{mmol}$ and $(\mathrm{C}) \mathrm{Cu}(\mathrm{II})=0.099 \mathrm{mmol}$. In all the systems the number of mmols of His is 0.50 .

\section{Structures of complexes}

When the second donor site of His is a nitrogen atom, marked bidentate behavior is frequently found, more so when the additional chelation results in a five- and seven-membered rings (Figure 3). Octahedral structures are proposed to the complexes of all the metal ions. Amino and imidazole nitrogen atoms of histidine can associate with hydrogen ions in physiological $\mathrm{pH}$ ranges. Hence, there is often significant competition between hydrogen and metal ion for these donor sites. This situation results in the simultaneous existence of a number of equilibria producing an array of successively protonated complexes. Hence, protonated complex species are detected in the present study. All the complexes were protonated in acidic $\mathrm{pH}$ region (up to $\mathrm{pH}$ 5). Under these conditions, the imidazole and $\alpha$-amino nitrogen atoms of hisitidine are protonated and carboxyl group is bonded to the metal ion. As the $\mathrm{pH}$ increases, the nitrogen atoms are deprotonated and coordinated to the metals. 
<smiles>CCCCCCOC(=O)C([NH3+])Cc1c[nH]c[nH+]1</smiles>

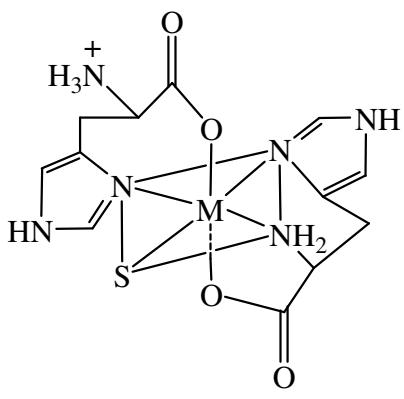

$\mathrm{ML}_{2} \mathrm{H}$

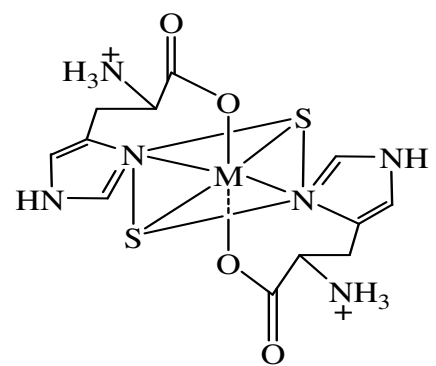

$\mathrm{ML}_{2} \mathbf{H}_{2}$

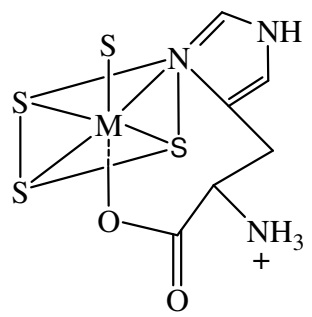

MLH

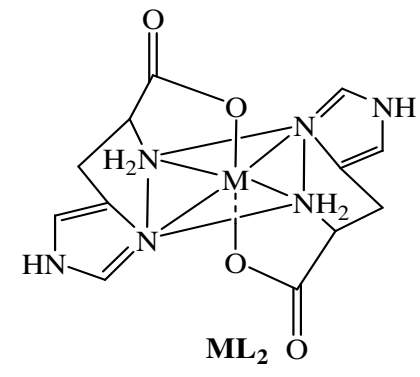

Figure 3. Structures of L-histidine complexes, where $\mathrm{S}$ is either solvent or water molecules.

\section{CONCLUSIONS}

The present biomimetic studies of metal ion complexes with L-histidine in DMSO-water mixtures indicate the formation of protonated complexes in acidic $\mathrm{pH}$ (up to $\mathrm{pH} 5$ ). Under these $\mathrm{pH}$ conditions, the imidazole and $\alpha$-amino nitrogen atoms of hisitidine are protonated and carboxyl group is bonded to the metal ion. As the $\mathrm{pH}$ increases, the nitrogen atoms are deprotonated and coordinated to the metals. The species formed due to the interaction of Lhistidine with the metals are MLH, ML, $\mathrm{ML}_{2} \mathrm{H}_{4}, \mathrm{ML}_{2} \mathrm{H}_{2}, \mathrm{ML}_{2} \mathrm{H}$ and $\mathrm{ML}_{2}$. The linear increase in $\log \beta$ values with $1 / \mathrm{D}$ of the medium indicates the dominance of electrostatic forces over nonelectrostatic forces. The influence of errors in the concentrations of ingredients on the 
magnitudes of stability constants is alkali $>$ acid $>$ ligand $>$ metal. Proximity of the protonation constants determined from proton ligand titration data to those retrieved from metal ligand titration data confirm the sufficiency of the models. High concentrations of the complex chemical species indicate that the metals are more amenable for transportation at biological $\mathrm{pH}$.

\section{ACKNOWLEDGEMENTS}

The authors (RS, AKB, BKNK) thank the UCG, New Delhi for financial support in the form of Fellowship under Faculty Development Programme.

\section{REFERENCES}

1. Leggett, J. (Ed.), Computational Methods for the Determination of Formation Constants, Plenum Press: New York; 1985.

2. Gans, P. Data Fitting in the Chemical Sciences, Wiley: Chichester; 1992.

3. Di Toro, D.M.; Allen, H.E.; Bergman, H.L. Meyer. J.S.; Paquin, P.R.; Santore, R.C. Environ. Toxicol. Chem. 2001, 20, 2383.

4. West, D.X.; Padhye, S.B.; Sonawane, P.B. Structure and Bonding, Vol. 76, SpringerVerlag: New York; 1991; pp 1-49.

5. Beraldo, H.; Gambino, D. Mini Rev. Med. Chem. 2004, 4, 31.

6. Chen, G.N.; Wu, X.P.; Duan, J.P.; Chen, H.Q. Talanta 1999, 29, 319.

7. Den Hertog, A.L.; Wong Fong Sang, H.W.; Kraayenhof, R.; Bolscher, J.G.; Van't Hof, W.; Veerman, E.C.; Nieuw Amerongen, A.V. Biochem. J. 2004, 379, 665.

8. Van Kan, E.J.; Demel, R.A.; Breukink, E.; vander Bent, A.; de Kruijff, B. Biochemistry 2002, 41, 7529.

9. Domingues, M.M.; Lopes, S.C.; Santos, N.C.; Quintas, A.; Castanho, M.A. Biophys. J. 2009, 96, 987.

10. Mason, A.J.; Bertani, P.; Moulay, G.; Marquette, A.; Perrone, B.; Drake, A.F.; Kichler, A.; Bechinger, B. Biochemistry 2007, 46, 15175.

11. Mason, A.J.; Gasnier, C.; Kichler, A.; Prévost, G.; Aunis, D. Metz-Boutigue, M.H.; Bechinger, B. Antimicrob. Agents Chemother. 2006, 50, 3305.

12. Hait, W.N.; Hambley, T.W. Cancer Res. 2009, 69, 1263.

13. Sundberg, R.J.; Martin, R.B. Chem. Rev. 1974, 74, 471.

14. Chow, S.T.; McAuliffe, C.A. in Prog. Inorg. Chem. Vol. 19, Lippard, S.J. (Ed.), Wiley: New York; 1975; p 51.

15. McDonald, C.C.; Phillips, W.D. J. Am. Chem. Soc. 1963, 85, 3736.

16. Carlson, R.H.; Brown, T.L. Inorg. Chem. 1966, 5, 268.

17. Sapper, H.; Paul, H.H.; Beinhauer, K.; Lohmann, W. Inorg. Chim. Acta 1985, 106, 25.

18. Henry, B.; Boubel, J.C.; Delpuech, J. J. Inorg. Chem. 1986, 25, 623.

19. Prasad, K.; Rao, A.K.; Mohan, M.S. J. Coord. Chem. 1987, 16, 251.

20. Cuadrado, J.A.; Zhang, W.; Hanga, W.; Majidi, V. J. Environ. Monit. 2000, 2, 355.

21. Manuela, M.; Robert, V.G.; Marcela, M.; Stefana, J.; Gabi, D. Romanian Biotechnol. Let. 2011, 16, 6242 .

22. Hansinger, R.P. Biochemistry of Nickel, Plenum: New York; 1993.

23. Gran, G. Analyst 1952, 77, 661.

24. Gran, G. Anal. Chim. Acta 1988, 206, 111.

25. Sailaja, B.B.V.; Kebede, T.; Rao, G.N.; Rao, M.S.P. Proc. Nat. Acad. Sci. (India) 2004, 74, 399. 
26. Jeffery, G.H.; Bassett, J.; Mendham, J.; Denney, R.C. (Eds.) Vogel's Text Book of Quantitative Chemical Analysis, 5th ed., Longman: London; 1991; p 557.

27. Padmaja, N.; Babu, M.S.; Rao, G.N.; Rao, R.S.; Ramana, K.V. Polyhedron 1990, 9, 2497.

28. Rao, G.N. Ph.D. Thesis, Andhra University, Visakhapatnam, India, 1989.

29. Gans, P.; Sabatini, A.; Vacca, A. Inorg. Chim. Acta 1976, 18, 237.

30. Babu, M.S.; Sukumar, J.S.; Rao, G.N.; Ramana, K.V.; Rao, M.S.P. Indian J. Chem. 1995, $34 \mathrm{~A}, 567$.

31. Briabanti, A.; Rao, R.S.; Babu, A.R.; Rao, G.N. Ann. Chim. (Italy) 1995, 85, 17.

32. Latha, M.P.; Rao, V.M.; Rao, T.S.; Rao, G.N. Acta Chim. Slov. 2007, 54, 160.

33. Vaisman, I.I.; Lyalina, R.B.; Kessler, Y.M.; Kumeev, R.S.; Gon-charov, V.V. Zh. Fiz. Khim. 1988, 62, 838 .

34. Kessler, Y.M.; Kumeev, R.S.; Vaisman, I.I.; Lyalina, R.B.; Bra-tishko, R.H. Ber. Bunsenges. Phys. Chem. 1989, 93, 770.

35. Templeton, E.F.G.; Kenney-Wallace, G.A. J. Phys. Chem. 1986, 90, 2896.

36. Simon. J.D. Acc. Chem. Res. 1988, 2, 128.

37. Born, M. Z. Phys. 1920, 1, 45. 